\title{
A hospital based cross sectional study on comorbid psychiatric problems in persons with epilepsy from north eastern part of India
}

\author{
Sajjadur Rehman ${ }^{\mathrm{a}, *}$, Kamal K. Kalita ${ }^{\mathrm{b}}$, Aparajeeta Baruah ${ }^{\mathrm{c}}$ \\ a Dept. of Psychiatry, Lady Hardinge Medical College New Delhi, 110001, India \\ ${ }^{\mathrm{b}}$ Dept. of Psychiatry, LGB Regional Institute of Mental Health Tezpur, Assam, 784001, India

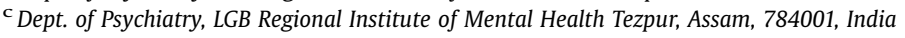

\section{A R T I C L E I N F O}

\section{Article history:}

Received 29 December 2016

Accepted 27 January 2017

Available online 8 February 2017

\section{Keywords:}

Epilepsy

Psychiatric comorbidity

Depression

Psychosis

Anxiety

\begin{abstract}
A B S T R A C T
Context: The relationship between epilepsy and psychiatric disorders has been recognized for a long time. Psychiatric disturbances like depression, anxiety disorder, psychosis, panic disorder, suicidal behavior etc are associated with epilepsy. Different demographic and clinical factors are associated with the onset of these psychiatric disturbances.

Aims: To study the prevalence of psychiatric comorbidity in persons with epilepsy. Also assess the different demographic and clinical factors and its relation with the presence of psychiatric comorbidity in persons with epilepsy.

Settings and design: It was a cross sectional observational study.

Methods and material: Diagnosed cases of epilepsy, attending Epilepsy Clinic, fulfilling the inclusion and exclusion criteria were recruited for the study. Patients were evaluated with Mini International Neuropsychiatric Interview (MINI) to see their psychiatric comorbidities and also the socio-demographic and clinical factors were assessed

Statistical analysis used: SPSS version 23.0 for Windows and Graph Pad InStat software trial version 3.1 was used for analysis.

Results: Psychiatric comorbidity was seen in 50\% subjects with comorbid with epilepsy. Depression $18 \%$, Psychosis 14\% and Anxiety Disorders 11\%, were the most commonly found psychiatric morbidities. Presence of partial seizures, frequent seizures, long duration of epilepsy and poor compliance to antiepileptic drug were significantly associated with presence of psychiatric comorbidity in persons with epilepsy.

Conclusions: Psychiatric comorbidities are very common in epilepsy. Psychosis associated with epilepsy is seen more in hospital settings. Depression and anxiety though commonly reported in studies are less commonly presented to tertiary care settings.
\end{abstract}

(C) 2017 Published by Elsevier, a division of RELX India, Pvt. Ltd on behalf of Indian Epilepsy Society.

\section{Introduction}

Since time immemorial, persons having epilepsy were seen as having mental disorder and suffered discrimination. Ignoring the possibility of having a comorbid psychiatric disorder became an accepted means of fighting the stigma associated with the illness. ${ }^{1}$ Epilepsy treated in neurology clinics focused more on the seizure semiology, its origin \& progression and relationship with the brain structures. As controlling the seizures improved the comorbid mental illness, hence psychiatric comorbidities were viewed as

\footnotetext{
* Corresponding author.

E-mail addresses: sajjadur25@gmail.com (S. Rehman),knkalita@gmail.com (K.K. Kalita), draparajeetabaruah396@gmail.com (A. Baruah).
}

secondary reaction to the underlying seizure disorder and therefore believed to require no treatment. ${ }^{2}$

The prevalence of psychiatric comorbidity is higher in persons with epilepsy than general population. It ranges from 19\%-62\% across studies. ${ }^{3,4} \mathrm{~A}$ gradient in prevalence is seen, with lower figures reported in community, higher among those visiting family physician and highest in speciality clinics. ${ }^{5}$

The psychiatric disorders associated with epilepsy are depression, anxiety disorder, panic disorder, obsessive compulsive disorder, psychosis and personality changes. Depression and anxiety were most frequently reported, though hospital studies reporting a higher prevalence of depression. ${ }^{6}$

High rates of unemployment, lower education and being single is reported more in persons with epilepsy than without. Psychiatric comorbidities were seen more among persons with focal seizure 
than that of generalized seizure, though this was not confirmed by other studies. Recurrent seizures due to reasons like seizure foci and compliance to antiepileptic drug may increase the risk of a comorbid mental disorder. ${ }^{7}$ Also use of antiepileptic drug itself can cause depression adding to the morbidity further. ${ }^{8}$

Recognition of a comorbid psychiatric disorder is hence important for both better control of seizure and better quality of life. The use standardized interview schedules like Structured Clinical Interview Schedule for DSM-IV Axis 1 disorder (SCID-1) used in previous studies can be time consuming for routine clinical use. ${ }^{6,9}$ These standardized interview schedules should be more time efficient, reliable, valid and comprehensive. Mini Neuropsychiatric Interview (MINI) is an effort of this type that focuses on current DSM-IV TR/ICD 10 Axis 1 disorders.

The study center caters to a population coming from various parts of the state of Assam and other adjoining north-eastern states of India. Assessing the psychiatric comorbidity will help in further refining the management of persons with epilepsy

The aim of the study is to see the prevalence of psychiatric comorbidity in persons having epilepsy attending to the tertiary mental health facility and to see association of it with the socio demographic and clinical factors present in the study population.

\section{Materials and methods}

\subsection{Place of study}

This is a hospital based cross sectional study that was done in outpatient department of LGB Regional Institute of Mental Health, Tezpur, India. Cases were taken over a period of one year. This is a tertiary level centre that caters to a large population coming from various parts of the state and also adjacent areas of the state covering the whole of north-eastern India.

\subsection{Ethical consideration}

The study was approved by Institutional Ethics Committee. Written informed consent was taken from the study subjects. They were informed about the purpose of the study and were ensured confidentiality. They were also informed about their right to withdraw any point of time during the study and told that their withdrawal from study would not have any impact in the treatment of the condition. Subjects who were diagnosed with any psychiatric disorder was referred to the psychiatric outdoor for consultation.

\subsection{Sample size and technique}

Taking the prevalence of $49 \%$ Axis 1 psychiatric disorders in persons with epilepsy from a multicentric study ${ }^{9}$ and allowable error of $10 \%$, sample size of 99.96 was reached. The patients taken were registered for Epilepsy Clinic held on each Monday of the week. Every 10th patient registered was taken for the interview till a sample size of 100 patients was reached by.

\subsection{Inclusion and exclusion criteria}

The patients included were in the age group of 18-60 years and diagnosed as having epilepsy as per International League Against Epilepsy (ILAE) criteria. ${ }^{10}$ Neuroimaging of brain was done to rule out any structural lesions. Patients with mental retardation, head injury, substance dependence, past history of mental illness prior to onset of seizure disorder were excluded.

\subsection{Socio demographic and clinical factors}

The sociodemographic details of the patients and clinical factors like seizure type, seizure frequency, and duration of seizure, duration and compliance to antiepileptic drugs were taken. The MINI questionnaire which is used to assess major adult Axis 1 psychiatric disorders in DSM-IV TR and ICD 10 was then administered. ${ }^{11}$

\subsection{Compliance}

Compliance means the "extent to which a patient acts in accordance with the prescribed dose and interval of a dosing regimen." 12 It is retrospective assessment of doses dispensed in relation to the dispensing period, often called as medication possession ratio, MPR, calculated as

$$
\begin{aligned}
\text { MPR } & =\frac{\text { No. of days supply held during a defined period }}{\text { No. of days during a defined period }} \\
& \times 100
\end{aligned}
$$

Table 1

\begin{tabular}{|c|c|}
\hline $\begin{array}{l}\text { Gender } \\
\text { - Male }\end{array}$ & $67(67 \%)$ \\
\hline - Female & $33(33 \%)$ \\
\hline $\begin{array}{l}\text { Age Distribution } \\
\text { - } 18-30 \text { years }\end{array}$ & $72(72 \%)$ \\
\hline - $31-40$ years & $15(15 \%)$ \\
\hline - 41-50 years & $11(11 \%)$ \\
\hline - 51-60 years & $2(2 \%)$ \\
\hline Age (Mean age) & $\begin{array}{l}26.61 \text { years } \\
(S D=10.26)\end{array}$ \\
\hline $\begin{array}{l}\text { Marital Status } \\
\text { - Married }\end{array}$ & $43(43 \%)$ \\
\hline - Unmarried & $57(57 \%)$ \\
\hline $\begin{array}{l}\text { Education } \\
\text { - Illiterate }\end{array}$ & $14(14 \%)$ \\
\hline - Primary School level & $29(29 \%)$ \\
\hline - High School level & $56(56 \%)$ \\
\hline - Graduation and above & $1(1 \%)$ \\
\hline $\begin{array}{l}\text { Occupation } \\
\text { - Student }\end{array}$ & $5(5 \%)$ \\
\hline - Homemaker & $19(19 \%)$ \\
\hline - Unemployed & $35(35 \%)$ \\
\hline - Employed & $41(41 \%)$ \\
\hline $\begin{array}{l}\text { Locality } \\
\text { - Rural }\end{array}$ & $23(23 \%)$ \\
\hline - Semi urban & $74(74 \%)$ \\
\hline - Urban & $3(3 \%)$ \\
\hline
\end{tabular}

Demographic Characteristics of the study sample N (\%). 
Table 2

Clinical Characteristics of the study sample, $\mathrm{N}(\%)$.

\begin{tabular}{|c|c|}
\hline $\begin{array}{l}\text { Type of Seizure } \\
\text { - Generalised seizure + Complex partial with secondary generalization } \\
\text { - Partial Seizure }\end{array}$ & $\begin{array}{l}68 \\
(68 \%) \\
32 \\
(32 \%)\end{array}$ \\
\hline $\begin{array}{l}\text { Seizure Frequency } \\
\bullet<10 \text { episodes/year } \\
\bullet>10 \text { episodes/year }\end{array}$ & $\begin{array}{l}75 \\
(75 \%) \\
25 \\
(25 \%)\end{array}$ \\
\hline $\begin{array}{l}\text { Duration of Seizure } \\
\text { - } 0-2 \text { years } \\
\text { - } 2-5 \text { years } \\
\text { - } 5 \text { years }\end{array}$ & $\begin{array}{l}16 \\
(16 \%) \\
50 \\
(50 \%) \\
34 \\
(34 \%)\end{array}$ \\
\hline $\begin{array}{l}\text { Family h/o Psychiatric Illness } \\
\text { - Present } \\
\text { - Absent }\end{array}$ & $\begin{array}{l}4(4 \%) \\
96 \\
(96 \%)\end{array}$ \\
\hline $\begin{array}{l}\text { h/o Febrile Seizure } \\
\text { - Present } \\
\text { - Absent }\end{array}$ & $\begin{array}{l}2(2 \%) \\
98 \\
(98 \%)\end{array}$ \\
\hline $\begin{array}{l}\text { Medication Status } \\
\text { - Single Anticonvulsant } \\
\text { - Poly Anticonvulsant }\end{array}$ & $\begin{array}{l}85 \\
(85 \%) \\
15 \\
(15 \%)\end{array}$ \\
\hline $\begin{array}{l}\text { Duration of Antiepileptic Drug } \\
\text { - } 0 \text {-1 year } \\
\text { - } 1-2 \text { years } \\
\text { - } 2-5 \text { years } \\
\text { - }>5 \text { years }\end{array}$ & $\begin{array}{l}36 \\
(36 \%) \\
22 \\
(22 \%) \\
38 \\
(38 \%) \\
4(4 \%)\end{array}$ \\
\hline $\begin{array}{l}\text { Compliance to Antiepileptic Drug } \\
\text { - Good } \\
\text { - Fair } \\
\text { - Poor }\end{array}$ & $\begin{array}{l}45 \\
(45 \%) \\
40 \\
(40 \%) \\
15 \\
(15 \%)\end{array}$ \\
\hline $\begin{array}{l}\text { Psychiatric Comorbidity } \\
\text { - Present } \\
\text { - Absent }\end{array}$ & $\begin{array}{l}50 \\
(50 \%) \\
50 \\
(50 \%)\end{array}$ \\
\hline
\end{tabular}

Table 3

Pattern of Psychiatric Comorbidity seen in Person with Epilepsy, N(\%).

\begin{tabular}{lc}
\hline Depression & $18(18 \%)$ \\
Dysthymia & $7(7 \%)$ \\
Panic Disorder & $1(1 \%)$ \\
OCD & $1(1 \%)$ \\
GAD & $9(9 \%)$ \\
Brief Psychotic Disorder & $4(4 \%)$ \\
Psychosis NOS & $10(10 \%)$ \\
\hline
\end{tabular}

Table 4

Association of Socio demographic and Clinical Variables with Psychiatric Comorbidity.

\begin{tabular}{|c|c|c|c|}
\hline $\begin{array}{l}\text { Socio demographic and clinical } \\
\text { variable }\end{array}$ & $\begin{array}{l}\text { Psychiatric } \\
\text { comorbidity } \\
\text { present }(\mathrm{n})\end{array}$ & $\begin{array}{l}\text { Psychiatric } \\
\text { comorbidity } \\
\text { absent }(\mathrm{n})\end{array}$ & $\begin{array}{l}\mathrm{p} \text { value } \\
\text { (significant } \mathrm{p} \\
\text { value }<0.05)^{*}\end{array}$ \\
\hline $\begin{array}{l}\text { Age } \\
\text { - } 18-30 \text { years }\end{array}$ & 37 & 37 & $\begin{array}{l}1 \\
\mathrm{df}=1\end{array}$ \\
\hline - >30 years & 15 & 15 & \\
\hline $\begin{array}{l}\text { Gender } \\
\text { - Male }\end{array}$ & 35 & 32 & $\begin{array}{l}0.52 \\
\mathrm{df}=1\end{array}$ \\
\hline - Female & 15 & 18 & \\
\hline $\begin{array}{l}\text { Marital Status } \\
\text { - Married }\end{array}$ & 20 & 23 & $\begin{array}{l}0.54 \\
\mathrm{df}=1\end{array}$ \\
\hline - Unmarried & 32 & 25 & \\
\hline $\begin{array}{l}\text { Education Status } \\
\text { - Illiterate }\end{array}$ & 6 & 8 & $\begin{array}{l}0.73 \\
\mathrm{df}=2\end{array}$ \\
\hline - Primary School level & 16 & 13 & \\
\hline - High School level and above & 28 & 29 & \\
\hline $\begin{array}{l}\text { Seizure Type } \\
\text { - Generalized/complex partial } \\
\text { with secondary generalization }\end{array}$ & 25 & 43 & $\begin{array}{l}<0.001^{*} \\
\mathrm{df}=1\end{array}$ \\
\hline - Partial Seizure & 25 & 7 & \\
\hline $\begin{array}{l}\text { Duration of Seizure } \\
\text { - } 0-2 \text { years }\end{array}$ & 4 & 12 & $\begin{array}{l}<0.014^{*} \\
\mathrm{df}=2\end{array}$ \\
\hline - 2-5 years & 23 & 27 & \\
\hline - $>5$ years & 23 & 11 & \\
\hline $\begin{array}{l}\text { Seizure Frequency } \\
\bullet<10 \text { episodes/year }\end{array}$ & 29 & 46 & $\begin{array}{l}<0.001^{*} \\
\mathrm{df}=1\end{array}$ \\
\hline - >10 episodes/year & 21 & 4 & \\
\hline $\begin{array}{l}\text { Medication Status } \\
\text { - Single Anticonvulsant }\end{array}$ & 40 & 45 & $\begin{array}{l}0.16 \\
\mathrm{df}=1\end{array}$ \\
\hline - Poly Anticonvulsant & 10 & 5 & \\
\hline $\begin{array}{l}\text { Duration of AED } \\
\text { - } 0-1 \text { year }\end{array}$ & 19 & 17 & $\begin{array}{l}0.86 \\
\mathrm{df}=2\end{array}$ \\
\hline - 1-2 years & 10 & 12 & \\
\hline - $>2$ years & 21 & 21 & \\
\hline $\begin{array}{l}\text { Compliance to AED } \\
\text { - Good }\end{array}$ & 18 & 27 & $<0.001^{*}$ \\
\hline - Fair & 17 & 23 & $\mathrm{df}=2$ \\
\hline - Poor & 15 & 0 & \\
\hline
\end{tabular}


In this study, patients maintaining a MPR score of $90-100 \%$ labeled as good compliance, $75-80 \%$ as fair compliance and $75 \%$ as poor compliance.

\subsection{Statistical analysis}

The statistical analysis of data was done by SPSS version 23.0 (SPSS South Asia Pvt Ltd., Bengaluru, Karnataka, India) and Graph Pad InStat trial software 3.1(USA). Test of significance was seen by chi square test and fisher exact test was applied for correction wherever applicable.

\section{Results}

The study included a total of 100 participants in the age range of $18-60$ years. Nearly three-fourth of the study population was less than 30 years of age and the mean age was 26.61 years with standard deviation of 10.26 . The profile of sociodemographic distribution is showed in Table 1 . Majority of the subjects were male (67\%), unmarried (57\%), belonged to a semi-urban background (74\%), educated up to high school level (56\%) and were employed (41\%), though the number of unemployed is also high (35\%).

Sixty eight percent subjects had a generalized seizure or complex partial seizure with secondary generalization and in one-fourth of the subjects (25\%), the seizures were poorly controlled as they were having $>10$ episodes of seizure a year as shown in Table 2 . Only $16 \%$ of the subjects had a seizure duration $<2$ years. In most cases there was no past history of febrile seizure or a family history of psychiatric illness. Eighty five percent of the subjects were on single anticonvulsant. Majority of the subjects were maintain on a good to fair compliance to anti epileptic drugs as shown in Table 2 . It is seen that $58 \%$ of the subjects were on treatment for last 2 years while only $4 \%$ on treatment for $>5$ years.

Psychiatric comorbidity was present in $50 \%$ of the subjects. The breakdown of them is shown in Table 3. Depression 18\%, psychosis $14 \%$ and anxiety disorders $11 \%$ were the most common psychiatric comorbidities.

Psychiatric comorbidity observed in the study population was studied for association with age, gender, marital status, educational status, seizure type, duration of seizure, seizure frequency, medication status, duration of AED and compliance to AED. The evidence for a strong association of psychiatric comorbidity was found with that of seizure type, seizure frequency, duration of seizure and compliance to AED as shown in Table 4. No other significant association was found across any other socio-demographic and clinical variables.

\section{Discussion}

We found that the prevalence of epilepsy is more in the younger age group and among males. Similar finding related to age group has been found in studies done in India and other developing countries. ${ }^{13,14}$ A young male is being more economically responsible is frequently referred for treatment or else there will be loss of productivity which may be a reason for such a trend. The educational level and marital status attained by persons with epilepsy is also getting hampered due to the disease process which is limiting them to attain an optimum level of functioning in the society. But no association was seen in our study with respect to presence of psychiatric comorbidity.

We found that psychiatric comorbidity was as high as $50 \%$, seen in 100 subjects who were having epilepsy. The subjects were assessed with MINI diagnostic interview schedule which is based on ICD 10 and DSM IV-TR. The overall psychiatric comorbidity quoted in our study is similar to studies done in India and abroad. A representation of different studies related to psychiatric comorbidity in epilepsy is shown Table 5 . Some discrepancies seen with respect to other studies may be attributable to the fact that the place of study is a mental health institute where referral or visits of patients is due to psychological and behavioral problems.

The overall prevalence of mood disorders, $25 \%$ was the highest among all the psychiatric comorbidities. Depression at $18 \%$ was most commonly found individual psychiatric disorder in the study population. Hospital based samples have reported higher rate of depression (27-58\%) than community based studies (9-22\%) in population with epilepsy. ${ }^{5}$ Psychosis was present in $14 \%$ of the study subjects. The prevalence of psychosis in other studies was reported at $2-9 \% .{ }^{21} \mathrm{~A}$ higher prevalence of $18 \%$ comorbid psychosis in epilepsy was reported by Filho et al., 2007 in a tertiary care, OPD based study using DSM-IV TR criteria. ${ }^{22}$ Comorbid anxiety disorder was present in $11 \%$ of the subjects. In a review of studies reported 19-25\% prevalence of anxiety. ${ }^{5}$ The above trends related with lower prevalence of depression \& anxiety and a higher prevalence of psychosis than that reported in previous studies can be attributable to two factors - the study area and the background

Table 5

Overview of Studies on Psychiatric Comorbidity in Epilepsy.

\begin{tabular}{|c|c|c|c|}
\hline Investigator & $\mathrm{N}$ (no. of subjects taken) & Instrument Used & $\begin{array}{l}\text { Psychiatric } \\
\text { Comorbidity }\end{array}$ \\
\hline $\begin{array}{l}\text { Currie et al (UK, } \\
\text { 1971) [15] }\end{array}$ & 666 hospital outpatients & Interview and case notes & $29 \%$ \\
\hline $\begin{array}{l}\text { Edeh \& Toone et al } \\
\quad \text { (UK 1987) [16] }\end{array}$ & 88 Outpatients & Clinical Interview Schedule (CIS) & $48 \%$ \\
\hline $\begin{array}{l}\text { Manchanda et al } \\
\text { (1996, Canada) } \\
\text { [17] }\end{array}$ & 300 epilepsy candidate for surgery & Present state examination (PSE) & $29 \%$ \\
\hline $\begin{array}{l}\text { Cyriac et al (2002, } \\
\text { India) [18] }\end{array}$ & 106 outpatients & ICD 10 symptom checklist \& ICD 10-DCR & $42.45 \%$ \\
\hline $\begin{array}{l}\text { Jones JE et al } \\
\text { (2005, USA) [9] } \\
\text { Multicentre trial }\end{array}$ & $\begin{array}{l}174 \text { subjects from } 5 \text { tertiary medical } \\
\text { centres }\end{array}$ & $\begin{array}{l}\text { Mini International Neuropsychiatric Interview (MINI) and mood disorder module } \\
\text { Structured Clinical Interview Schedule (SCID) }\end{array}$ & $49 \%$ \\
\hline $\begin{array}{l}\text { Jacob R et al } \\
\text { (2010, India) [6] }\end{array}$ & 88 outpatients & Structured Clinical Interview Schedule (SCID) -DSM IV version & $28.7 \%$ \\
\hline $\begin{array}{l}\text { Amruth G et al } \\
\text { (2014, India) [19] }\end{array}$ & $\begin{array}{l}80 \text { outpatients subjects each with } \\
\text { epilepsy, asthma and control }\end{array}$ & Mini International Neuropsychiatric Interview (MINI) & $32.5 \%$ \\
\hline $\begin{array}{l}\text { Desai S et al } \\
\quad(2014 \text {, India) [20] }\end{array}$ & $\begin{array}{l}50 \text { subjects with epilepsy planned for } \\
\text { surgery }\end{array}$ & Mini International Neuropsychiatric Interview (MINI) & $52 \%$ \\
\hline
\end{tabular}


of the population who are coming for consultation. Majority of the population come from a sub-urban or rural area. It is likely that awareness or the dysfunction associated with mood and anxiety disorders may be lesser than that of psychosis, where behavioral problems are more acute and severe.

There was evidence for strong association of partial seizures, poorly controlled seizure, longer duration of seizure disorder and poor compliance to AED with presence comorbid psychiatric conditions in patients with epilepsy. These findings are in line with previous studies. ${ }^{6,23-25}$ Titlic M et al., 2009 cited that in patients with temporal lobe foci, hypometabolism in extratemporal regions increase the vulnerability for depression. ${ }^{5}$ Also poorly controlled seizures and longer duration of seizure disorder decrease the functionality and deterioration in quality of life adding further to the psychological morbidity. Poor compliance to anticonvulsants which may lead to poorly controlled seizure which may have a bidirectional relationship with presence of comorbid psychiatric disorder. ${ }^{26}$ Such an association needs further clarification.

This study is an attempt to highlight the clinical profile and comorbid psychological problems of patients with epilepsy from north eastern part of India. There are obvious limitations of doing a cross sectional study and a small population but this study has used a scale which is structured and is less time consuming.

\section{Conclusion}

Psychiatric comorbidity is patients with epilepsy are common. Depression, psychosis and anxiety disorder were the most commonly reported problem in the study population. Awareness in the general population is needed regarding psychological issues in patients with epilepsy especially with respect to depression and anxiety disorders which may sometimes go unnoticed. Patients with partial seizure need more attention for psychological issues. Maintaining compliance to anticonvulsants will not only control seizure frequency but also independently reduce the overall comorbidity.

\section{References}

1. Kanner AM. Psychiatric issues in epilepsy: the complex relation of mood, anxiety disorders, and epilepsy. Epilepsy Behav. 2009;15(1):83-87.

2. Manchanda R. Psychiatric disorders in epilepsy: clinical aspects. Epilepsy Behav. 2002;3(1):39-45.

3. Hermann BP, Seidenberg M, Bell B. Psychiatric comorbidity in chronic epilepsy: identification, consequences, and treatment of major depression. Epilepsia. 2000;41(Suppl. 2):S31-41.

4. Gaitatzis A, Trimble MR, Sander JW. The psychiatric comorbidity of epilepsy. Acta Neurol Scand. 2004;110(4):207-220.
5. Titlic M, Basic S, Hajnsek S, Lusic I. Comorbidity psychiatric disorders in epilepsy: a review of literature. Bratisl Lek Listy. 2009;110(2):105-109.

6. Jacob R, Tharyan P. Psychiatric comorbidity and quality of life in people with epilepsy. Ger J Psychiatry. 2010;13(2):79-85.

7. Swinkels WA, Kuyk J, van Dyck R, Spinhoven P. Psychiatric comorbidity in epilepsy. Epilepsy Behav. 2005;7(1):37-50.

8. Robertson MM, Trimble MR, Townsend HR. Phenomenology of depression in epilepsy. Epilepsia. 1987;28(4):364-372.

9. Jones JE, Hermann BP, Barry JJ, Gilliam F, Kanner AM, Meador KJ. Clinical assessment of Axis I psychiatric morbidity in chronic epilepsy: a multicenter investigation. J Neuropsychiatry Clin Neurosci. 2005;17(2):172-179.

10. Proposal for revised clinical and electroencephalographic classification of epileptic seizures. From the Commission on Classification and Terminology of the International League Against Epilepsy. Epilepsia (1981) 22 (4) 489-501.

11. Sheehan DV, Lecrubier Y, Sheehan KH, et al. The Mini-International Neuropsychiatric Interview (M.I.N.I.): the development and validation of a structured diagnostic psychiatric interview for DSM-IV and ICD-10. J Neuropsychiatry Clin Neurosci. 1998·59(Suppl. 20)22-33 quiz 4-57.

12. Cramer JA, Roy A, Burrell A, et al. Medication compliance and persistence: terminology and definitions. Value Health. 2008;11(1):44-47.

13. Mendizabal JE, Salguero LF. Prevalence of epilepsy in a rural community of Guatemala. Epilepsia. 1996;37(4):373-376.

14. Radhakrishnan K, Pandian JD, Santhoshkumar T, et al. Prevalence, knowledge, attitude, and practice of epilepsy in Kerala, South India. Epilepsia. 2000;41 (8):1027-1035.

15. Currie S, Heathfield KW, Henson RA, Scott DF. Clinical course and prognosis of temporal lobe epilepsy. A survey of 666 patients. Brain. 1971;94(1):173-190.

16. Edeh J, Toone B. Relationship between interictal psychopathology and the type of epilepsy: results of a survey in general practice. Br J Psychiatry. 1987;151:95101.

17. Manchanda R, Schaefer B, McLachlan RS, et al. Psychiatric disorders in candidates for surgery for epilepsy. J Neurol Neurosurg Psychiatry. 1996;61 (1):82-89.

18. Cyriac N, Sureshkumar PN, Kunhikoyamu AM, Girija AS. Social factors and psychopathology in epilepsy. Neurol India. 2002;50(2):153-157.

19. Amruth G, Praveen-Kumar S, Nataraju B, Kasturi P. Study of psychiatric comorbidities in epilepsy by using the Mini International Neuropsychiatric Interview. Epilepsy Behav. 2014;33:94-100.

20. Desai S, Shukla G, Goyal V, et al. Changes in psychiatric comorbidity during early postsurgical period in patients operated for medically refractory epilepsy-a MINI-based follow-up study. Epilepsy Behav. 2014;32:29-33.

21. Schmitz B, Wolf P. Psychosis in epilepsy: frequency and risk factors. J Epilepsy. 1995;8(4):295-305.

22. Filho GM, Rosa VP, Lin K, Caboclo LO, Sakamoto AC, Yacubian EM. Psychiatric comorbidity in epilepsy: a study comparing patients with mesial temporal sclerosis and juvenile myoclonic epilepsy. Epilepsy Behav. 2008:13(1):196-201.

23. Perini GI, Tosin C, Carraro C, et al. Interictal mood and personality disorders in temporal lobe epilepsy and juvenile myoclonic epilepsy. J Neurol Neurosurg Psychiatry. 1996;61(6):601-605.

24. Babu CS, Satishchandra P, Sinha S, Subbakrishna DK. Co-morbidities in people living with epilepsy: hospital based case-control study from a resource-poor setting. Epilepsy Res. 2009;86(2-3):146-152.

25. Faught E, Duh MS, Weiner JR, Guerin A, Cunnington MC. Nonadherence to antiepileptic drugs and increased mortality: findings from the RANSOM Study. Neurol. 2008;71(20):1572-1578.

26. Bragatti JA, Torres CM, Londero RG, et al. Prevalence of psychiatric comorbidities in temporal lobe epilepsy in a Southern Brazilian population. Arq Neuro Psiquia. 2011;69:159-165. 